\title{
El perfil del periodista en la era digital: Una aproximación académica para comprender sus desafíos y oportunidades
}

The profile of journalists in the digital age: An academic approach to understand their challenges and opportunities

\author{
José Santillán Arruz* \\ Escuela Profesional de Ciencias de la Comunicación, \\ Universidad de San Martín de Porres, Perú
}

\section{Resumen}

¿Cuál es el perfil del periodista que demanda actualmente una corporación mediática? ¿Se requiere de un periodista especializado o un periodista «todo terreno»? ¿Qué tipo de asignaturas se dictan en las universidades para responder a las expectativas y necesidades de las empresas periodísticas? Desde que las tecnologías digitales tomaron por asalto las salas de redacción, se han formulado estas inquietudes sin hallar una respuesta satisfactoria. La convergencia sigue siendo, por ahora, un desafío para muchos medios de comunicación que, en el camino, deben hacer frente a las exigencias de un nuevo tipo de lector y de una caprichosa audiencia. El éxito laboral de un graduado en periodismo dependerá, en gran parte, de su preparación individual y profesional. Para las empresas periodísticas, la responsabilidad de las universidades es grande. Precisamente por eso, las corporaciones mediáticas deben buscar un acercamiento al mundo académico y de esta forma dar a conocer sus necesidades. Este artículo pretende aproximar algunas respuestas a las inquietudes planteadas.

Palabras clave: periodismo; convergencia; universidad; asignaturas; formación profesional; perfil profesional

Este es un artículo Open Access bajo la licencia Creative Commons Atribución-NoComercial-Compartirlgual 4.0 


\begin{abstract}
Which is the profile of the journalist that a media corporation currently demands? Is a specialized journalist or a 'multitasking' journalist required? What kind of subjects are taught in universities to meet the expectations and needs of journalism companies? Since digital technologies stormed the newsrooms, these concerns have been raised without finding a satisfactory answer. Convergence remains, for now, a challenge for many media outlets that must face in their path the demands of a new type of reader or capricious audience. The job success of journalism graduates will largely depend on their individual and professional preparation. According to journalism companies, universities have great responsibility on this matter. Precisely for that reason, media corporations should seek to approach the academic environment and, in this way, make their needs known. This paper aims to provide some answers to the aforementioned concerns.
\end{abstract}

Keywords: journalism; convergence; university; subjects; professional training; professional profile

\title{
Introducción
}

La última década ha sido quizá la más difícil para el ejercicio del periodismo. Los cambios producidos por el empuje de la globalización económica y el impacto de las nuevas tecnologías, obligaron a que muchas empresas periodísticas replanteen sus estrategias de comercialización y apliquen los ajustes necesarios en el ámbito de recursos humanos, para hacer frente a esta nueva crisis de orden mediático que desde entrado ya el nuevo siglo tuvo dimensiones planetarias.

Los periodistas, considerados como la columna vertebral de cualquier medio de comunicación, fueron los primeros en ser llamados para asumir el novísimo y no menos indefinido perfil profesional que exigieron en su momento las corporaciones mediáticas ante el súbito desafío tecnológico: reporteros que, además de escribir para un periódico, tenían que hacerlo también para una página web, tomar fotografías, realizar videos, hacer entrevistas en vivo ante una cámara y, por supuesto, conocer algunas otras aplicaciones digitales que les permitan difundir contenidos originales y de 
calidad en diversas plataformas. El periodista «todoterreno» era indispensable y parecía no tener salida.

No era vana, entonces, la impaciencia de los medios por reclutar a este nuevo tipo de profesionales, caracterizados principalmente por ser, en principio, periodistas con un perfil estrechamente vinculado al conocimiento de la tecnología digital. El objetivo de las empresas mediáticas era claro: el control de, al menos, un rincón del gigantesco espacio virtual que ofrecía Internet $y$, además, el dominio de todas las herramientas y plataformas posibles para hacer frente a una antojadiza audiencia y a un nuevo tipo de lector que busca contenidos más creativos, cercanos y útiles. La revista Caretas fue la primera (12 de enero de 1995) que lanzó su versión digital. El diario La República hizo lo mismo en mayo de 1996. Ese año hicieron lo mismo el diario El Peruano y Radio Programas del Perú (RPP) y el 15 de enero de 1997 lo hace también El Comercio.

A partir de entonces, las discusiones sobre el futuro del periodismo fueron creciendo. El modelo de negocio; la forma de consolidar la llamada "convergencia», que pronto se estableció como palabra clave en el vocabulario de los periodistas y empresarios de medios; y, finalmente, la clase de contenidos para proponer a la audiencia y lectoría. A pesar de todo, no faltó el debate acerca del perfil del periodista que se requería en esta nueva etapa marcada por el uso sistemático del espacio virtual y las herramientas digitales.

Es en ese contexto que se dieron vehementes discusiones acerca de las competencias y la calidad periodística de los hombres de prensa. Por un lado, los periodistas tradicionales reprochaban a sus colegas digitales por la falta de rigurosidad, el lenguaje duro y la escasez de precisión en los datos que se difundían mediante los portales web y las redes sociales. Era muy común escuchar que los periodistas digitales eran considerados simples técnicos $u$ obreros de la información. Estos últimos, sin embargo, veían como verdaderos «dinosaurios» a los periodistas clásicos, tradicionales o convencionales.

El periodismo ya no es solo escribir, sostenían los bisoños colegas que, provistos de una tableta o un teléfono inteligente, daban rienda suelta a su creatividad y criticaban el escaso conocimiento en tecnologías digitales de los que formaban parte de la vieja guardia periodística. No tardaron los reclamos 
internos en las corporaciones mediáticas por un periodista que, además de escribir bien, domine las tecnologías digitales. Sin embargo, no hubo o, al menos, no se conoce de algún acercamiento de los medios al mundo académico para dar a conocer sus necesidades.

¿Cuál es el perfil del periodista deseado? Para hallar respuestas, se realizó una encuesta a 24 periodistas -entre ellos, reporteros, redactores y editores de mesa- para conocer los requisitos exigidos por algunos medios de comunicación a los profesionales que quieren ejercer el periodismo.

Para complementar y descubrir si la formación de futuros periodistas en la universidad responde a dichas expectativas, se hizo una revisión panorámica de las mallas curriculares que presentaban las diferentes facultades y escuelas donde se forman comunicadores y profesionales de prensa. De esta manera, se contrastó si las asignaturas que se impartían garantizaban el perfil profesional exigido por los medios de comunicación. Todo ello, nos dio algunas luces respecto de los desafíos y oportunidades que tienen los graduados en periodismo.

Es necesario señalar que en el desarrollo de ese trabajo de investigación, se observó que el perfil solicitado por los medios masivos destacaba tres características principales: juventud, buena redacción y experiencia en el manejo de herramientas digitales y redes sociales.

\section{El periodista y la convergencia}

Hoy, las salas de redacción, por modestas que sean, ya no son las mismas que ostentaban las nobles y pesadas máquinas de escribir como emblema del trabajo que desarrollaban los periodistas. Hasta mediados de los años 80, algunas salas de redacción lucían orgullosas sus vetustas Smith-Corona, Remington, Brother $\mathrm{u}$ Olimpia. Todas ellas eran testigos de largas noches de desvelo, apasionadas discusiones sobre política o deportes, así como del titular que debería lucirse en la portada del día siguiente.

Eran épocas en las que se usaban las cuartillas y el papel de calco o carbón para redactar una nota y tener una copia de respaldo. Fue una etapa en la que los periodistas se peleaban por usar el único teléfono de la sala de redacción 
para confirmar algún dato, además de escribir tres o cuatro historias, pero intentando siempre que al menos una de ellas sea la noticia del día, el tema de portada. A mediados de los años 90, y a puertas del nuevo siglo, las ruidosas máquinas de escribir empezaron a ser reemplazadas paulatinamente por enormes monitores de video y sus teclados plásticos. Era la computadora que había llegado para quedarse.

Las salas de redacción de los principales medios peruanos se mostraban así, mucho más modernas, más informatizadas. Habían cambiado, además, su tradicional configuración rectangular (ubicación de escritorios uno detrás de otro) por una distribución cuasi circular, de modo tal, que los periodistas de plataformas convencionales, digitales, además de editores centrales y de sección, trabajasen en un espacio que permita una comunicación más abierta $\mathrm{y}$, de paso, controlar y conocer de cerca el flujo y calidad de los contenidos informativos.

Como si fuera poco, los periodistas pasaron a tener su propio teléfono móvil inteligente, a partir de lo cual las noticias se dan con un amplio sentido multiplataforma. Gracias a Internet se afianzan las páginas web y aparecen los primeros blogs. Todo ello cambia las formas de hacer periodismo; desde la investigación, elaboración y producción de información hasta la difusión de noticias. Simplemente se dejaba de lado el papel por el revolucionario pixel y con ello se extendía la partida de nacimiento al ciberperiodismo.

Desde entonces, los medios ven en la tecnología digital una herramienta fundamental para hacer periodismo en todos sus procesos, es decir, en su totalidad. El uso de la tecnología y las herramientas digitales en el periodismo son hoy son una necesidad impostergable y una obligación. No se trata de afirmar, entonces, que todo lo que el ciberespacio otorga está única y exclusivamente al servicio del periodismo digital como se cree o piensa. Así lo confirma la práctica del trabajo periodístico cotidiano. Al respecto Verón y Sabés (2007) señalan:

Incluso sin hablar específicamente de los medios digitales, todas las facetas del trabajo periodístico convencional se están viendo afectadas por la incorporación de estas tecnologías. Este proceso de cambio, por medio de las nuevas tecnologías (que ya no son tan nuevas sino que son 
las que tenemos y utilizamos los periodistas y comunicadores para transmitir información), lo estamos viviendo los profesionales, lo estamos disfrutando $\mathrm{y}$, en parte, lo estamos sufriendo. ¿Es imprescindible que un periodista sepa utilizar las nuevas tecnologías? La respuesta no puede ser más tajante: sí. Como se acaba de señalar, es fundamental el uso de estas herramientas para desarrollar las viejas destrezas que se han asociado al periodismo (selección, análisis, síntesis, verificación, contraste y jerarquización). (p. 106)

Todo esto, sin embargo, no sería posible sin la llamada convergencia. Esa impostergable y necesaria integración multisectorial entre el periodismo convencional y el periodismo digital. Para la totalidad de medios de comunicación peruanos, la convergencia no fue otra cosa que la unificación de sus diferentes redacciones. Esto, por supuesto, significó también que la ansiada sinergia de recursos humanos tuviera como efecto la selección de los profesionales más competentes y aptos para enfrentar la nueva era tecnológica.

Muchos periodistas convencionales -muy experimentados, aunque no lograron adaptarse a la nueva era tecnológica- fueron despedidos y reemplazados por bisoños colegas, muy diestros en el manejo de herramientas digitales y redes sociales, pero demasiado inexpertos en la redacción periodística o el reconocimiento de un hecho noticioso.

Por esa razón, la convergencia sigue siendo un desafío para muchos medios masivos y conglomerados de prensa. Esto, porque aún hay algunos periódicos, emisoras de radio y estaciones de televisión que tienen pendiente la tarea de adaptarse y renovarse por el impacto de las nuevas tecnologías. El periodismo convergente es una obligación y un proceso continuo si se quiere sobrevivir en medio de la dura competencia que significa lograr la fidelidad de la audiencia o de los lectores. Gracias a Internet, el periodismo del nuevo siglo es otro y todo indica que seguirá cambiando por el impacto tecnológico. Salaverría (2006) nos dice al respecto:

Con la universalización de internet, ocurrida a lo largo de los últimos diez años, el periodismo ha experimentado un impacto profundo. Nada igual le había ocurrido al periodismo como mínimo desde hace tres generaciones. En concreto, desde que comenzaron a realizarse las 
primeras emisiones de televisión, a finales de los años 1930, ningún otro medio de comunicación social había nacido en el mundo. La generación actual de periodistas tiene el privilegio de estar asistiendo al nacimiento de un nuevo medio, que está llamado a reconfigurar el periodismo de este siglo XXI. Con ello, también es seguro que la propia profesión de periodista cambiará. De momento, aunque ha pasado muy poco tiempo desde la aparición del nuevo medio, los efectos no se han dejado esperar. Todo hace suponer, por tanto, que a medio y largo plazo, el impacto de internet en el periodismo puede ser mucho más importante de lo que algunos imaginan. (p. 183)

En medio de todos estos cambios, no es extraño que actualmente se hable de ciberperiodismo. ¿Pero, qué es? Una definición aceptada mayoritariamente, es la propuesta por Díaz Noci y Salaverría (2003): «Aquella especialidad del periodismo que emplea el ciberespacio para la investigación, la elaboración y, muy especialmente, la difusión de contenidos periodísticos» (p. 17).

Aunque el término ciberperiodismo y ciberperiodista son muy utilizados en Europa y en otros países de habla hispana para referirse a los periodistas que realizan sus labores utilizando plataformas y herramientas digitales, aquí en el Perú, se prefiere utilizar aún la expresión periodista digital, en alusión al profesional de prensa que ha logrado incorporar las nuevas tecnologías para producir información en uno o más soportes mediáticos. Hoy es impensable dejar de hablar de ciberperiodismo o periodismo digital en un mundo globalizado con alta competitividad, donde la inmediatez es casi una obligación en la producción de noticias.

\section{El perfil deseado: lo que exigen los medios}

Dada la importancia que reviste el periodismo convergente, se realizó una encuesta para conocer el perfil profesional del periodista que las corporaciones mediáticas requieren como parte de su planilla de trabajadores. El estudio se realizó entre enero y junio de 2019 con 24 profesionales de prensa de algunos medios (selección aleatoria) que respondieron a las siguientes preguntas:

1. ¿Cuáles son los requisitos que exigen a los periodistas que egresan de las universidades? 
2. ¿Cuáles son los requisitos que exigen a los periodistas que ya cuentan con experiencia profesional?

3. ¿Se exige conocimiento de herramientas digitales?

4. ¿Se exige cultura general?

\section{Otras exigencias}

La encuesta busca obtener una lista de requerimientos y características que debe reunir un profesional de prensa, tanto en diarios, radio y televisión. Los resultados obtenidos se observan en la Tabla 1.

\section{Tabla 1}

Los perfiles del peruiodista del siglo XXI

\begin{tabular}{|c|c|c|}
\hline $\begin{array}{l}\text { Medio de } \\
\text { prensa }\end{array}$ & $\begin{array}{l}\text { Perfil periodista recién egresado } \\
\text { de la universidad (periodista junior) }\end{array}$ & $\begin{array}{l}\text { Perfil periodista con } \\
\text { experiencia profesional }\end{array}$ \\
\hline El Comercio & $\begin{array}{l}\text { - Con cultura general } \\
\text { - Conocimientos de la coyuntura actual } \\
\text { - Que redacte bien y conozca con } \\
\text { claridad los géneros periodísticos } \\
\text { - Que identifique con facilidad la noticia } \\
\text { - Que sepa hacer titulares } \\
\text { - Dominio de la redacción web } \\
\text { - Manejo de SEO } \\
\text { - Manejo de redes sociales } \\
\text { - Dominio de herramientas y aplicaciones } \\
\text { digitales (fotografía, audio y video) para } \\
\text { periodismo, entre ellas: } \\
\text { Genially (fotografía y contenido } \\
\text { interactivo), Thinglink (Imágenes } \\
\text { interactivas), Infogram (infografías), } \\
\text { Timeline JS (líneas de tiempo) } \\
\text { - De preferencia con conocimientos de } \\
\text { idioma adicional }\end{array}$ & $\begin{array}{l}\text { - Con amplia y sólida cultura } \\
\text { - Aeneral } \\
\text { - Amplio manejo y dominio de } \\
\text { fuentes de información } \\
\text { - Además de todo lo exigido al } \\
\text { periodista junior, el personal de } \\
\text { prensa con experiencia debe ser } \\
\text { capaz de: } \\
\text { - Realizar entrevistas en vivo, si } \\
\text { fuera el caso, para diferentes } \\
\text { plataformas } \\
\text { - Transmisión de información } \\
\text { en vivo, si fuera el caso, para } \\
\text { diferentes plataformas }\end{array}$ \\
\hline La República & $\begin{array}{l}\text { - Con cultura general } \\
\text { - Conocimientos de la coyuntura actual } \\
\text { - Que redacte bien y conozca con } \\
\text { claridad los géneros periodísticos } \\
\text { - Que identifique con facilidad la noticia } \\
\text { - Que sepa hacer titulares }\end{array}$ & $\begin{array}{l}\text { - Con amplia y sólida cultura } \\
\text { - Aeneral } \\
\text { - Amplio manejo y dominio de } \\
\text { - Duentes de información } \\
\text { - Un periodista con experiencia en } \\
\text { medios y en redacción web, }\end{array}$ \\
\hline
\end{tabular}


- Dominio de la redacción web

- Manejo de SEO

- Manejo de redes sociales

- Con conocimientos de idioma adicional (no indispensable) debe entrenarse en la rapidez y en el manejo de herramientas como Google Analytics para identificar qué es lo que buscan las audiencias y no perder tiempo en notas que tal vez no le resulten efectivas para el posicionamiento en la web

\begin{tabular}{|c|c|c|}
\hline $\begin{array}{c}\text { Andina } \\
\text { Editora Perú }\end{array}$ & $\begin{array}{l}\text { - Amplia cultura informativa sobre la } \\
\text { coyuntura actual } \\
\text { - Con buena redacción y que identifique } \\
\text { con claridad lo que es noticia } \\
\text { - Dominio de la redacción web } \\
\text { - Manejo de SEO } \\
\text { - Manejo de herramientas digitales y } \\
\text { redes sociales } \\
\text { - Con conocimientos de idioma } \\
\text { adicional (no indispensable) }\end{array}$ & $\begin{array}{l}\text { - Con amplia cultura informativa sobre } \\
\text { la coyuntura actual } \\
\text { - Dominio de fuentes de información } \\
\text { - Dominio de redacción web } \\
\text { - Capaz de dirigir y transmitir noticieros } \\
\text { y entrevistas en vivo }\end{array}$ \\
\hline $\begin{array}{c}\text { América TV } \\
\text { Canal N }\end{array}$ & $\begin{array}{l}\text { - Conocimiento de la coyuntura actual } \\
\text { - Cultura general } \\
\text { - Que sepa comunicar ideas } \\
\text { - Con buena redacción y que identifique } \\
\text { - con rapidez la noticias } \\
\text { - Manejo de herramientas digitales } \\
\text { - Manejo de redes sociales } \\
\text { - Manejo de fuentes informativas }\end{array}$ & $\begin{array}{l}\text { - Amplia cultura y conocimiento de la } \\
\text { coyuntura actual } \\
\text { - Buen comunicador } \\
\text { - Buen entrevistador } \\
\text { - Dominio de redacción web } \\
\text { - Dominio de fuentes de información }\end{array}$ \\
\hline $\begin{array}{c}\text { Radio } \\
\text { Programas } \\
\text { del Perú (RPP) }\end{array}$ & $\begin{array}{l}\text { - Conocimiento de la coyuntura actual } \\
\text { - Cultura general } \\
\text { - Que sepa comunicar ideas y que } \\
\text { interactúe con facilidad con las } \\
\text { personas } \\
\text { - Con buena redacción y que identifique } \\
\text { con claridad y rapidez la noticia } \\
\text { - Manejo y dominio de herramientas } \\
\text { digitales } \\
\text { - Manejo de redes sociales }\end{array}$ & $\begin{array}{l}\text { - Amplia cultura y conocimiento de la } \\
\text { - Buyuntura actual } \\
\text { - Buen comunicador } \\
\text { - Buen entrevistador } \\
\text { - Dominio de redacción web } \\
\text { Dominio de fuentes de información }\end{array}$ \\
\hline $\begin{array}{l}\text { Exitosa } \\
\text { Noticias }\end{array}$ & $\begin{array}{l}\text { - Conocimiento de la coyuntura actual } \\
\text { - Cultura general } \\
\text { - Con buena redacción y que identifique } \\
\text { con claridad y rapidez la noticia } \\
\text { - Manejo de redes sociales }\end{array}$ & $\begin{array}{l}\text { - Amplia cultura y conocimiento de la } \\
\text { coyuntura actual } \\
\text { - Buen comunicador } \\
\text { - Buen entrevistador } \\
\text { - Conocimiento y dominio de redes } \\
\text { sociales }\end{array}$ \\
\hline
\end{tabular}


De acuerdo con lo obtenido, a todos los periodistas se les exige un dominio o, por lo menos, un manejo aceptable de herramientas digitales y redes sociales. En algunos casos, como ocurre con El Comercio, ya tienen claro que tipo de aplicaciones digitales son las que se usan. Se exige también tener buena redacción, además de saber identificar la noticia. Del mismo modo, es un requisito tener una mínima formación en cultura general, en otras palabras, ser una persona leída, cultivada intelectualmente. Este, sin embargo, parece ser el «talón de Aquiles» de los periodistas jóvenes. Una debilidad y amenaza que afecta la calidad y credibilidad del periodismo y del periodista, respectivamente. Son muy pocos los que tienen conocimientos aceptables de historia, política, economía o asuntos internacionales.

El conocimiento de un idioma extranjero no es obligatorio, pero la globalización mundial, la utilización de documentos en inglés y portugués (como ocurrió con los Casos WikiLeaks y Lavajato, por ejemplo), además del continuo intercambio informativo con periodistas de otras naciones, obliga, sin duda, a que los hombres de prensa deban conocer una segunda lengua.

Aunque no forma parte del estudio, es pertinente señalar que además del perfil exigido, se pudo observar que el grueso de los periodistas que integran las redacciones de los medios que fueron consultados son jóvenes cuyas edades se encuentran entre los 24 y 30 años en promedio. Esto parece ser muy común en la era digital. Aguado-Terrón y Torres (2010) explican al respecto:

Esos factores, entre otros, han incidido en que el peso de las iniciativas individuales haya recaído en mayor medida en la generación más joven, ligada de forma natural a las nuevas tecnologías, lo que ha facilitado la implantación de una nueva dinámica de trabajo basada en soportes digitales. El móvil, la cámara de fotos digital, los portátiles con conexión móvil a Internet y las grabadoras digitales son herramientas básicas para expandir la convergencia en las rutinas periodísticas. (p. 143)

Durante la última década Internet es el sustento del periodismo convergente, al punto que no hay medio masivo que esté exento de sus ventajas. Esto es lo que ha modelado, finalmente y en buena cuenta, el perfil del periodista actual. Con referencia a esto Salaverría (2006) nos dice: 
Hoy en día, Internet se ha convertido en una fuente de información imprescindible para cualquier periodista, sea cual sea el medio para el que trabaje y el área temática en la que se desenvuelva. Y lo es por varios motivos. He aquí algunas de las razones más importantes por las que la red se ha vuelto hoy tan necesaria para los periodistas a la hora de investigar: - Da acceso a información actualizada al minuto; - Además de textos, permite hallar otros contenidos multimedia, tales como imágenes y sonidos; - Multiplica el número de fuentes informativas y documentales, tanto desde una perspectiva geográfica como temática; - Ofrece nuevas formas de relación con las personas, gracias sobre todo al correo electrónico, lo que facilita notablemente la localización y entrevista asincrónica de las fuentes; - Sirve como herramienta para verificar la información, gracias a los buscadores, bases de datos y enciclopedias digitales; - Gracias a la facilidad para revisar la oferta informativa de otros medios, es una fuente de ideas para reportajes y coberturas periodísticas en general. (p. 178)

Un hecho importante, que forma parte de los nuevos perfiles profesionales que demandan los medios masivos, ha sido el satisfacer sus necesidades de nuevos cargos y responsabilidades, los cuales se han generados a partir de la convergencia periodística y que, en la actualidad, son tareas cotidianas en periódicos, estaciones de radio y televisión. Así tenemos al editor web, community manager, analista de tráfico informativo, gestor de contenidos, administrador de redes sociales, etc. El impacto de las nuevas tecnologías ha sido determinante en ese sentido.

\section{El otro lado de la moneda: cultivar a un periodista}

La formación de un periodista, sin embargo, no acaba con la tecnología. Se requiere mucho más que una preparación en programas o aplicaciones digitales para elaborar, producir, editar y difundir información de interés y relevancia social. El otro gran desafío está, también, en eliminar la imagen de un periodismo escasamente creíble, parcializado en algunos temas o que pone primacía en el activismo político, antes que velar por la rigurosidad y calidad de sus contenidos. La formación humanística de los futuros periodistas parece ser, en ese sentido, una demanda para garantizar una adecuada 
profesionalización. Durante los últimos años se ha abierto un amplio debate al respecto.

Lo planteado cobra especial relevancia si consideramos que los periodistas son intérpretes de la realidad social, establecen la agenda de debate en torno a los grandes temas nacionales y luego encauzan a la opinión pública con, al menos, tres propósitos fundamentales que en teoría deberían darse: integrar a la sociedad, construir ciudadanía y fortalecer la democracia. Esto, lamentablemente, parece que en el Perú, no está ocurriendo. Real, Agudiez y Príncipe (2007) señalan, en ese sentido, su preocupación por la importancia que tiene el periodismo:

El periodista no es un mero intermediario o mediador entre el hecho y el público. Es un intérprete, el artífice que ayuda a entender la realidad que nos rodea, los sucesos que acontecen y afectan a nuestra existencia en el mundo. El profesional de la información periodística no debe caracterizarse por captar sin más los hechos, sino buscar con rigor y minuciosidad el significado que esos acontecimientos poseen, pues bien sabemos que ver no es comprender. La objetividad y la veracidad del periodista en esta ocupación son elementos esenciales e imprescindibles. Deben hacerse todos los esfuerzos necesarios para garantizar que el contenido de las noticias sea fiel, esté libre de prejuicios y se ajuste al contexto, y que todas las opiniones implicadas sean presentadas de modo imparcial. (p. 194)

Por su parte López (como se citó en Oliva, 2014) sostiene que «las tecnologías actuales han abierto nuevas ventanas para favorecer el flujo informativo, aunque no han conseguido poner fin a los desequilibrios, sobre todo, se ha avanzado poco en el camino de garantizar la calidad de la información» (p.3).

Entre el 18 y 19 de abril de 2016, la Universidad Externado, situada en la ciudad de Bogotá, Colombia, fue escenario del VI Encuentro de Programas Acreditados por el Consejo Latinoamericano de Acreditación de la Educación en Periodismo (CLAEP). La inauguración de dicha cita académica, denominada ¿Para quién estamos formando periodistas: audiencias o medios?, estuvo a cargo del rector de esa casa de estudios, Juan Carlos Henao. Asimismo, 
participaron la decana de esa casa de estudios, Luz Amalia Camacho y el entonces presidente de CLAEP, Tony Pederson.

Algunas de las discusiones y conclusiones a las que se llegó en aquella reunión pueden resumirse de la siguiente manera:

1. En las ponencias recogidas se perfila como paradigma de enseñanza una formación más humanista del futuro periodista o comunicador social. De hecho, se ha señalado que base de esa formación debe tener como principios: Una sólida formación ética, con cultura política y conocimiento de la historia. «Las nuevas tecnologías ya no son suficientes», se precisó.

2. Se destacó la necesidad de formar buenos ciudadanos, que a la larga serán los comunicadores e intermediarios de una sociedad que requiere profesionales con un alto sentido de responsabilidad social para poder entender y repensar el papel que deben asumir los medios de comunicación.

3. Por ello, se plantea una relación más estrecha entre la universidad y los medios para responder con claridad a las preguntas sobre qué clase de periodistas queremos y qué clase de periodistas estamos formando.

4. Frente a esta situación se destaca la importancia de los sílabos y currículos por competencias, los cuales permiten el desarrollo de habilidades y capacidades profesionales, laborales, sociales y académicas.

Para el CLAEP, órgano dependiente de la Sociedad Interamericana de Prensa (SIP), no deja de ser importante el uso de herramientas y aplicaciones digitales en la formación profesional de periodistas, pero las nuevas tecnologías «ya no son suficientes». La formación ética y los conocimientos de cultura política e historia son tan o más importantes que las nuevas tecnologías. Es decir, el periodista debe ser una persona cultivada, que inspire respeto y pueda desenvolverse con seriedad y credibilidad en la sociedad.

Solo en Lima hay 22 universidades, entre nacionales y privadas, dedicadas a la formación de comunicadores y periodistas en facultades o escuelas de Ciencias de la Comunicación, Comunicación Social y Humanidades. En algunos casos, la formación es holística y en otros se prefiere la especialización 
por áreas afines al desarrollo del periodismo, como ocurre con Diseño Gráfico, Fotografía, Audiovisuales o Relaciones Públicas y Publicidad.

Pero ¿̇las universidades responden al perfil del periodista convergente que los medios masivos demandan y exigen en la actualidad? Eso es lo que veremos en la Tabla 2, que muestra en resumen las mallas curriculares, hasta julio del 2019, de algunas casas de estudios superiores y las asignaturas que sobresalen en la formación de los futuros profesionales de prensa. 


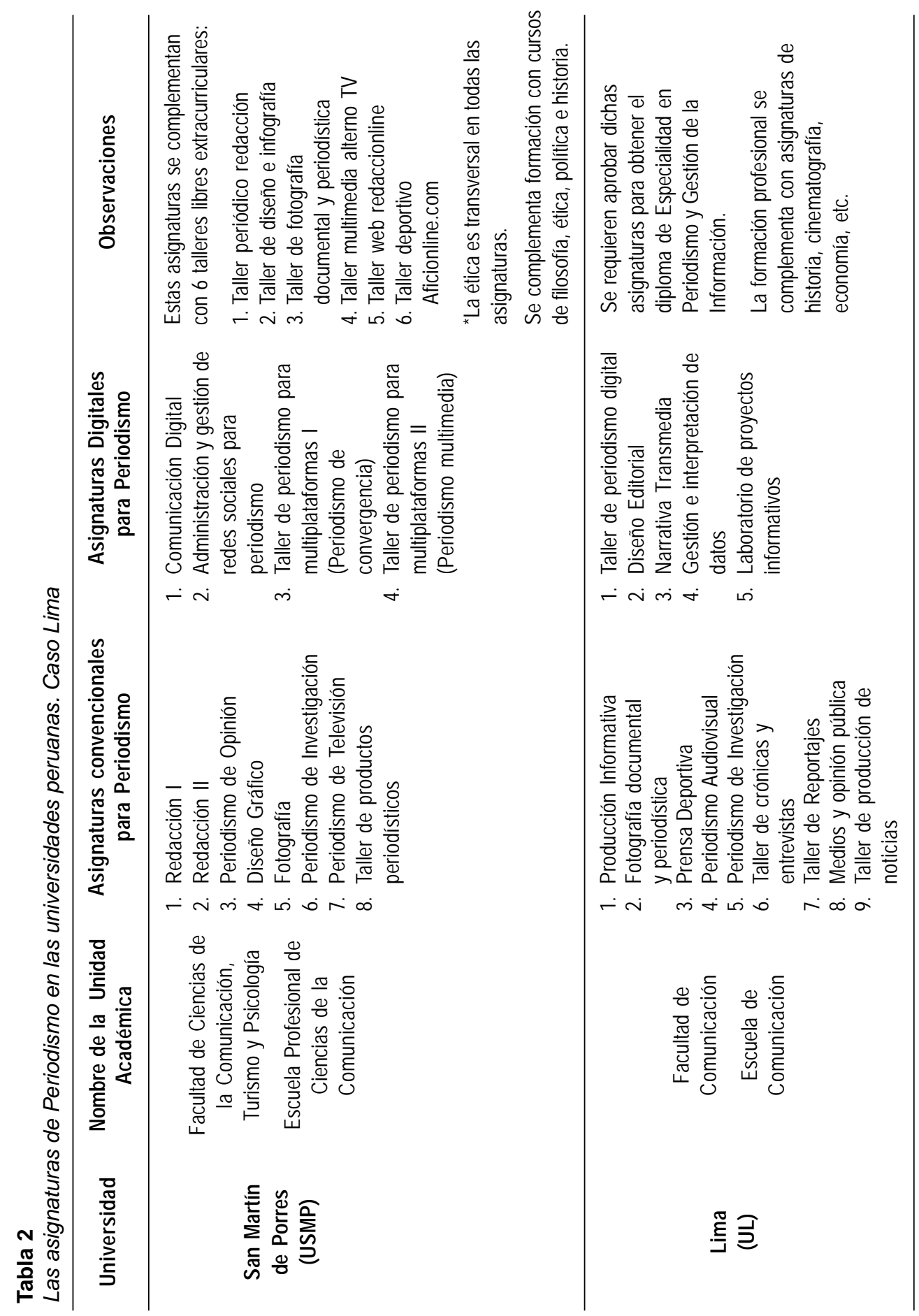



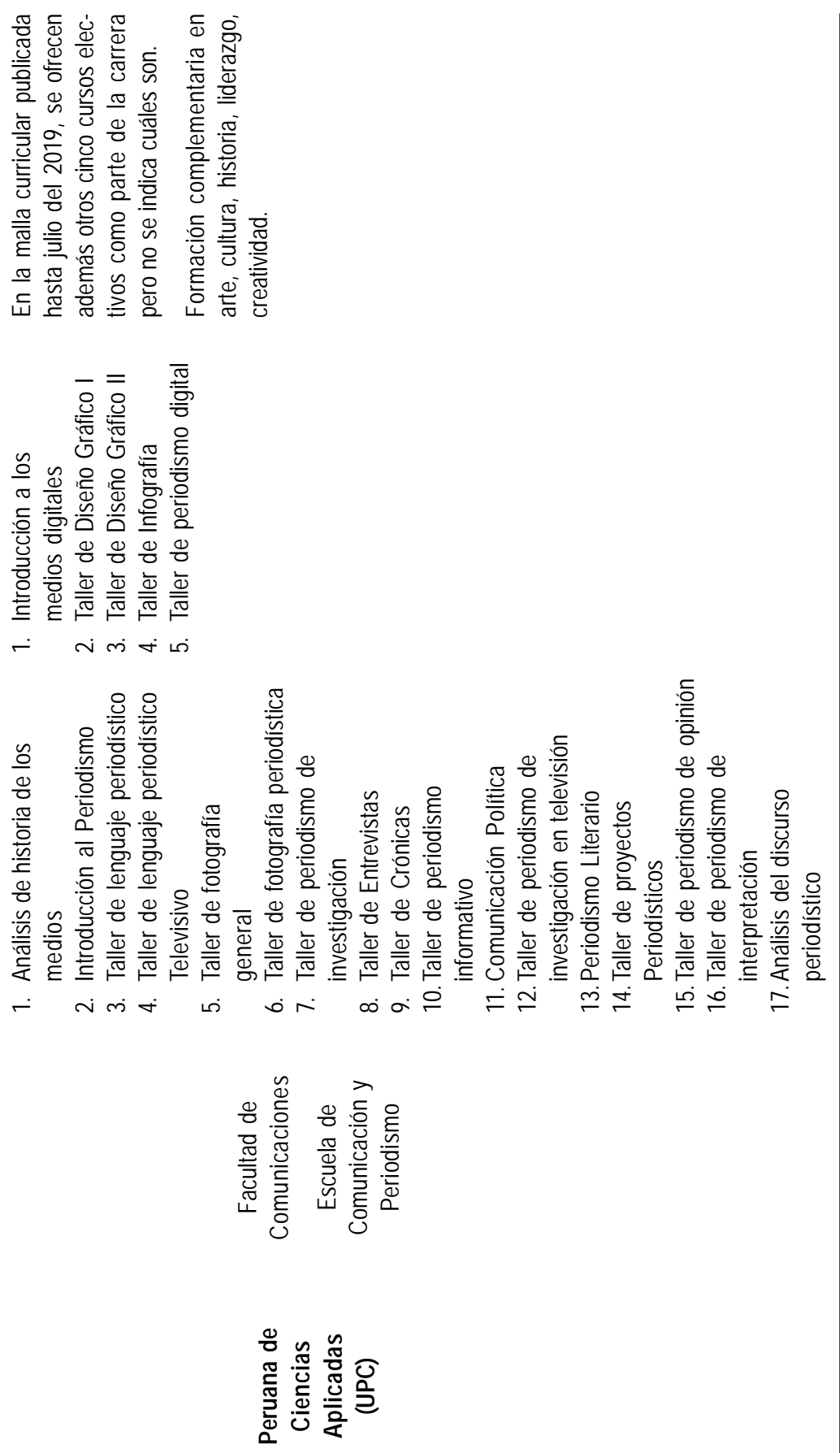

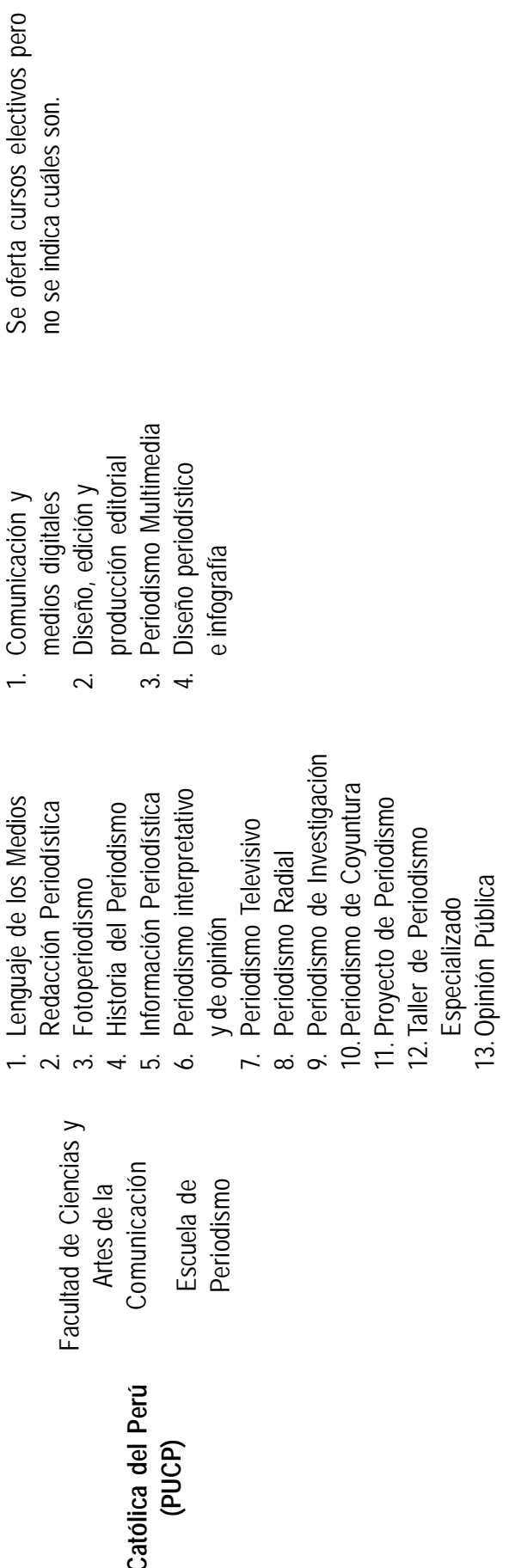
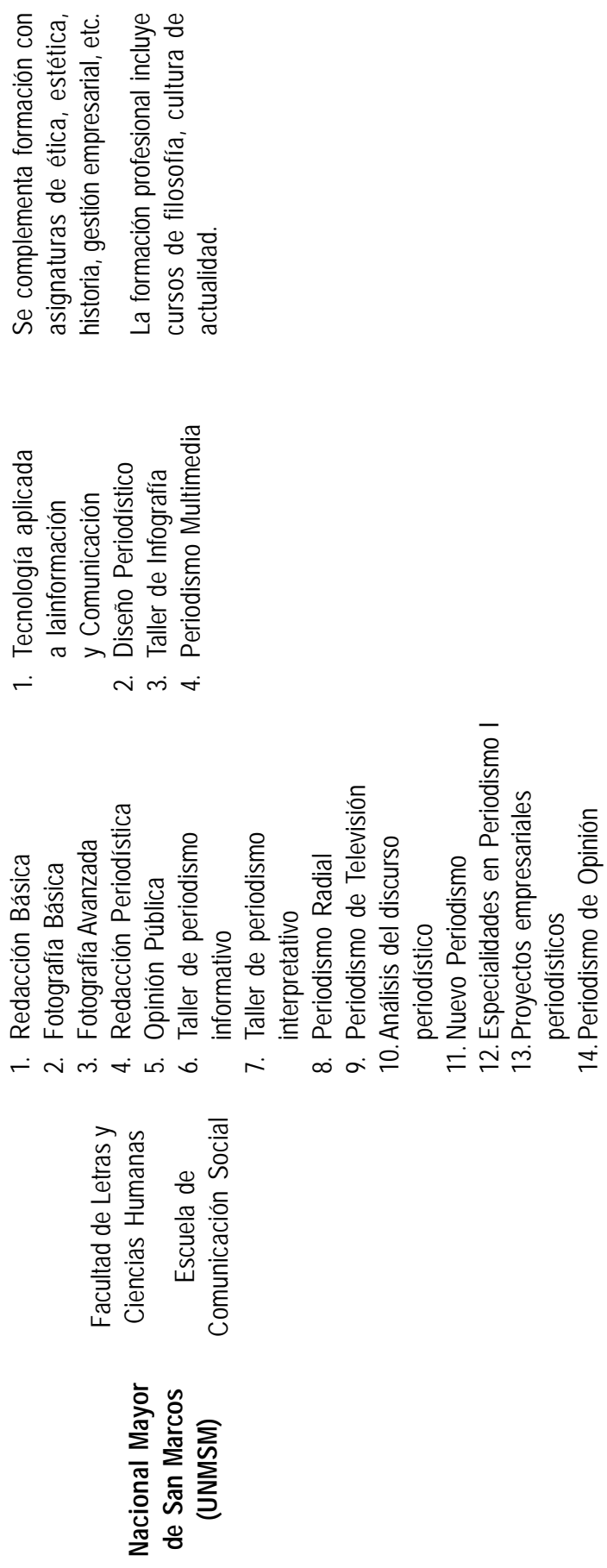

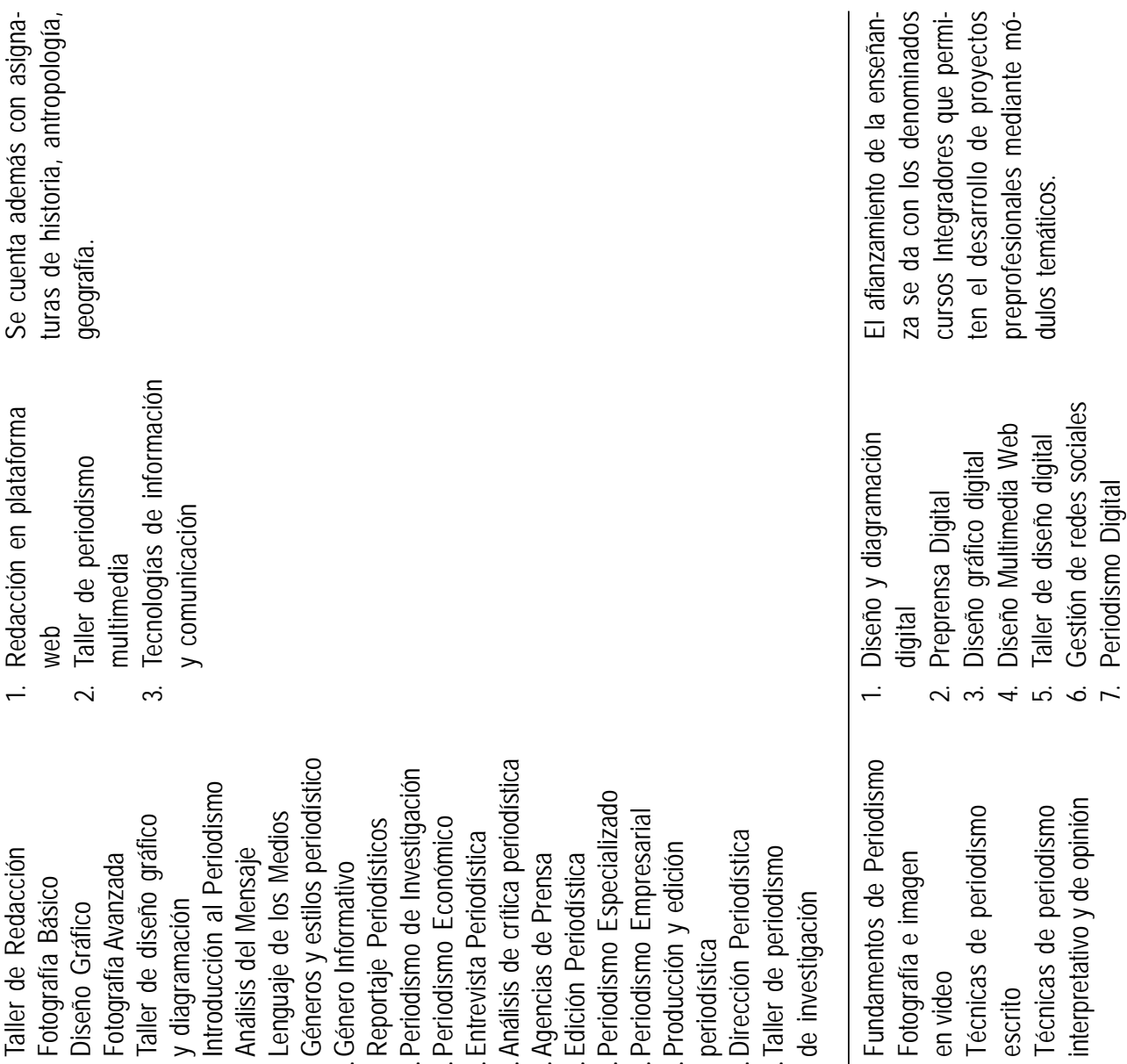

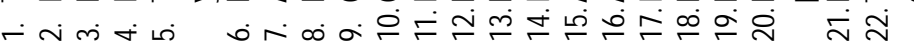
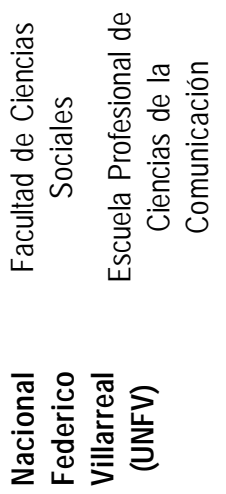

$\rightarrow N M \vec{T}$
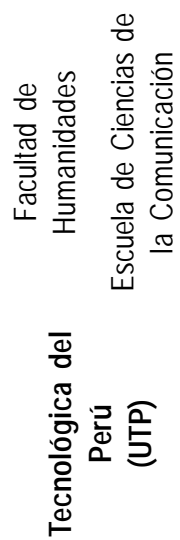


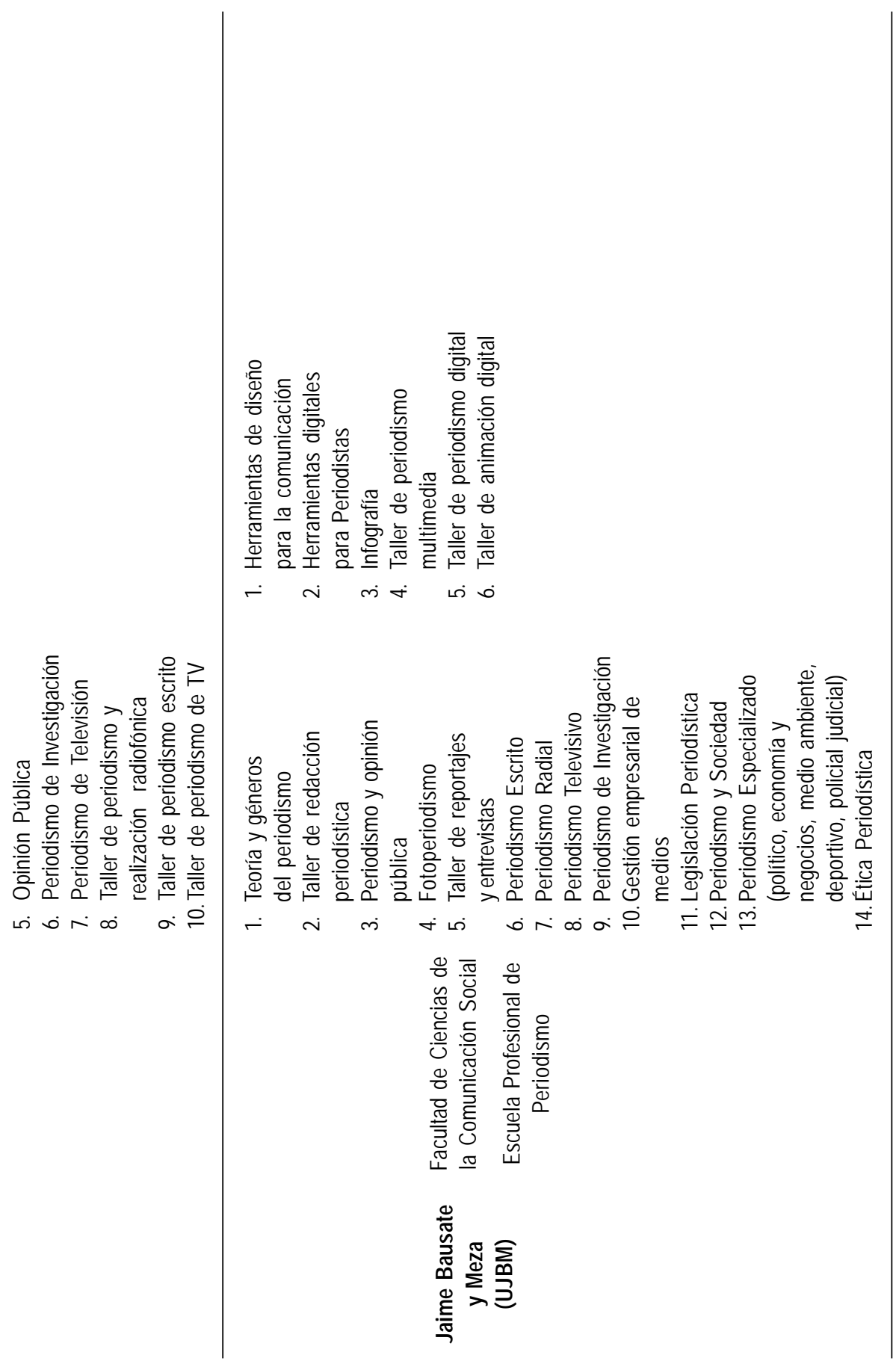



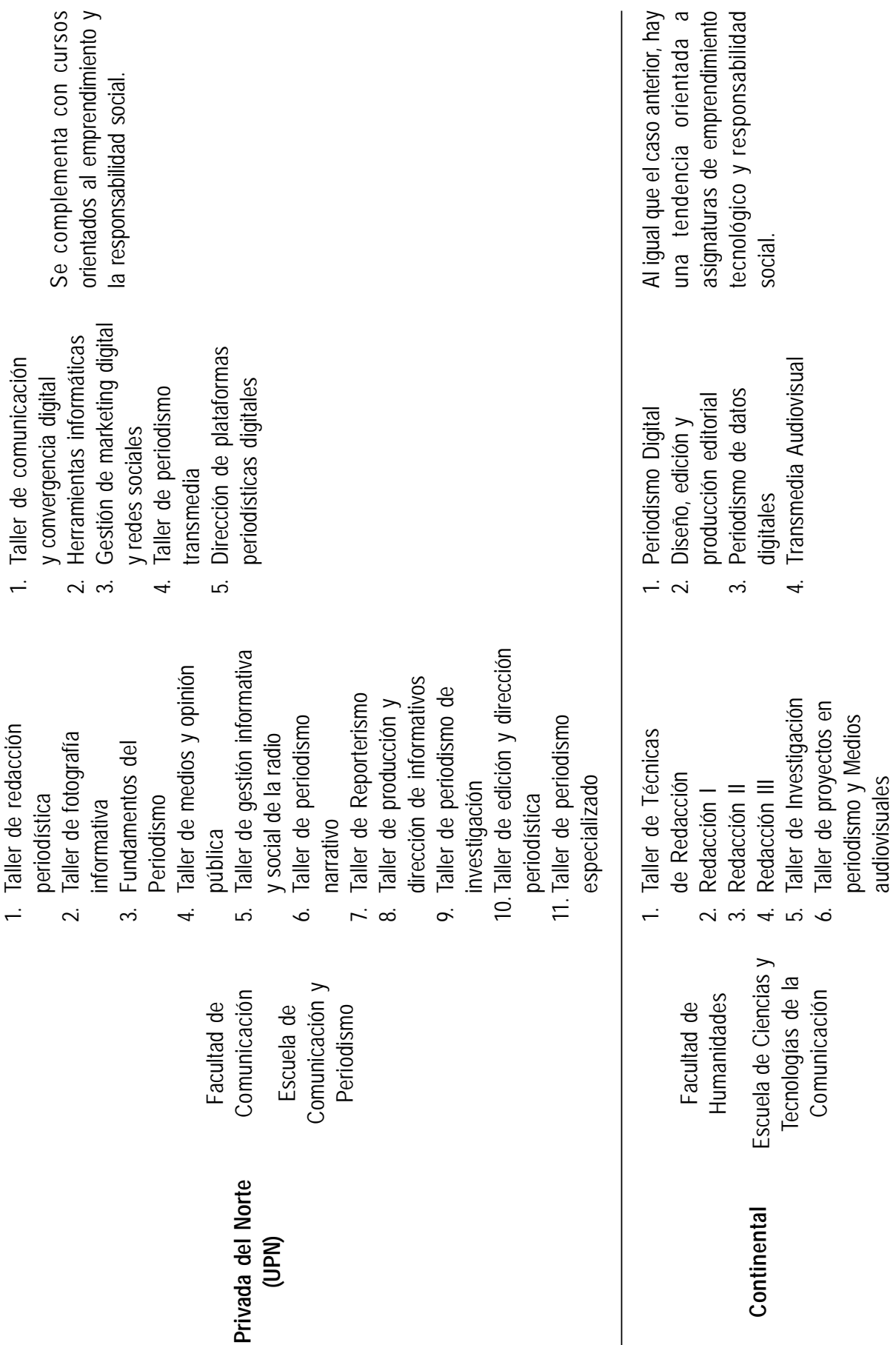

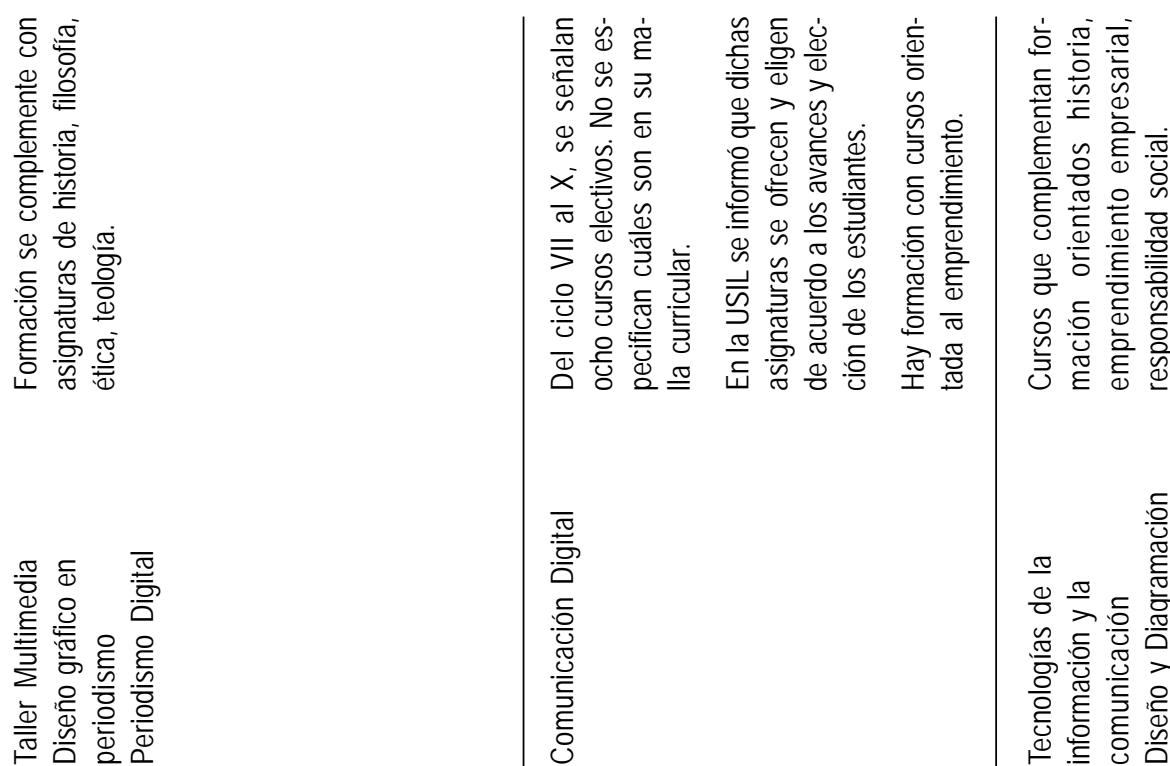

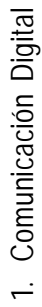

든

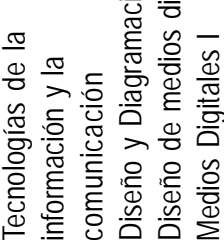

$\rightarrow N M$

- $\quad$ m
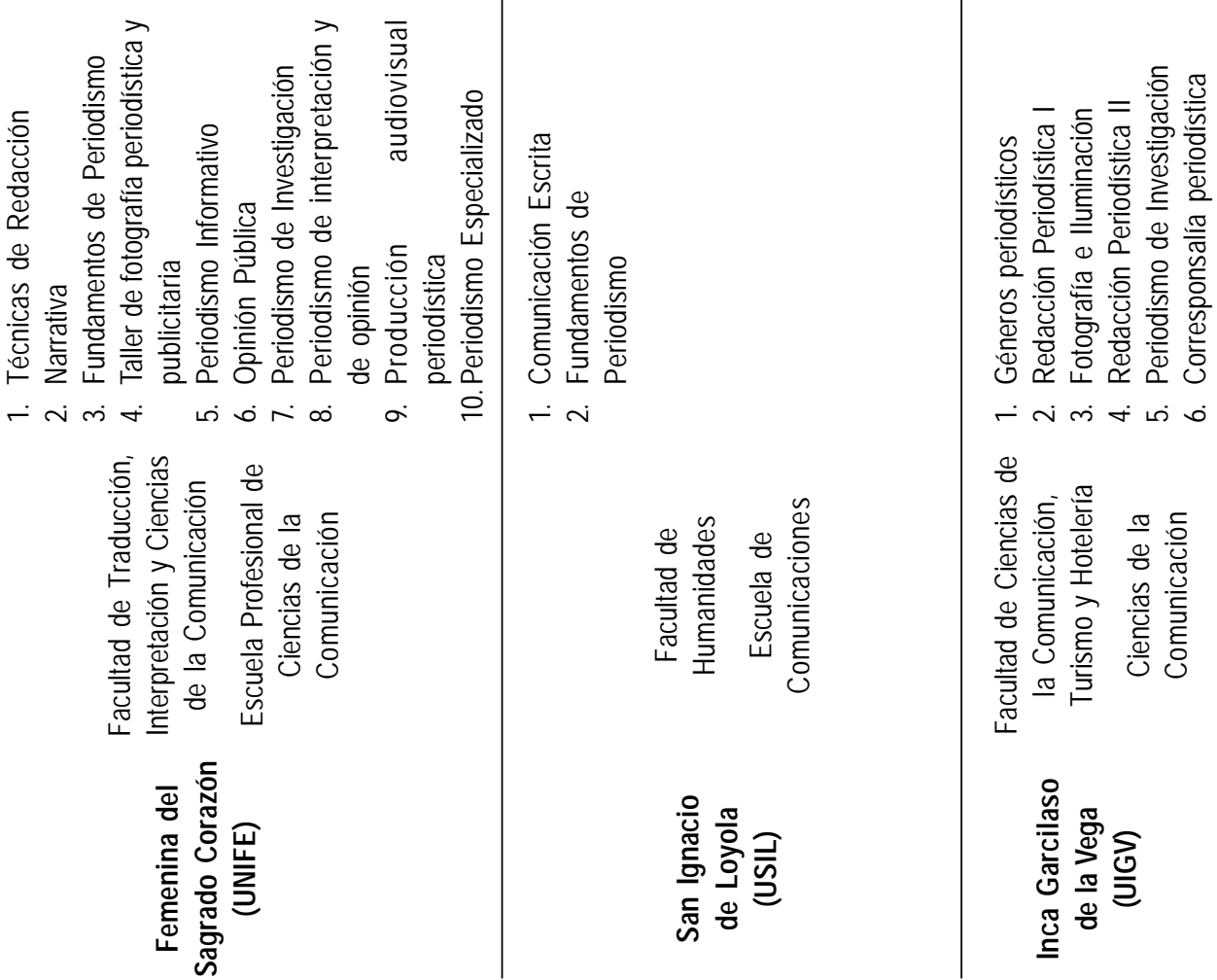


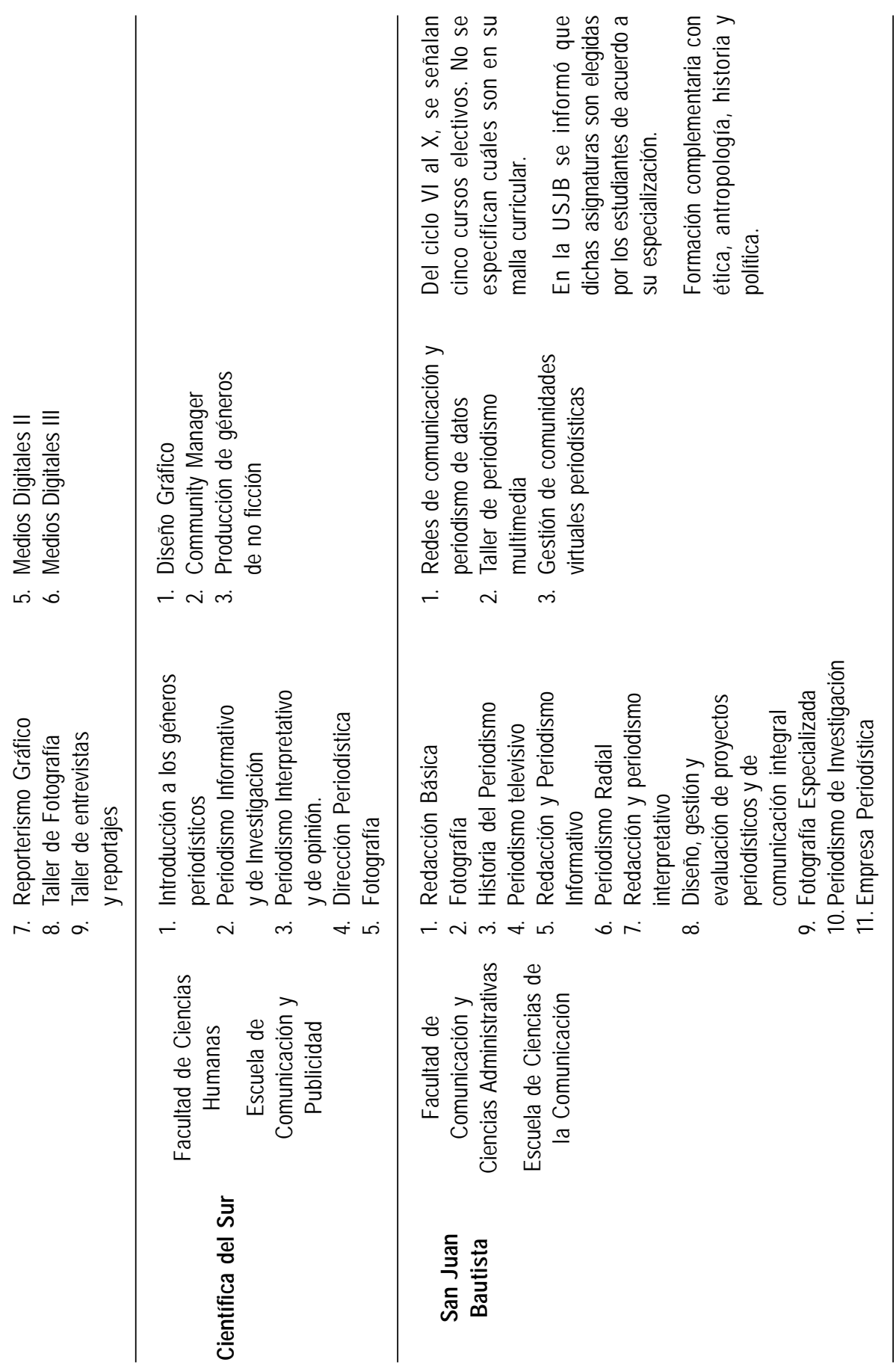




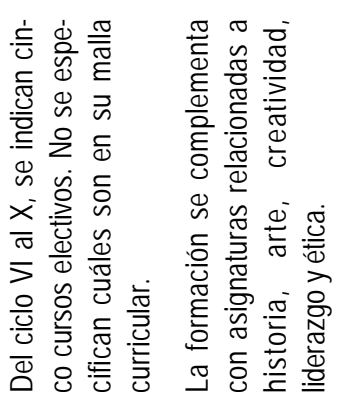

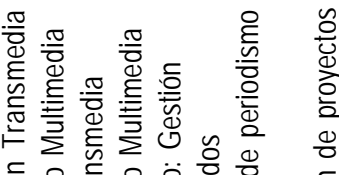

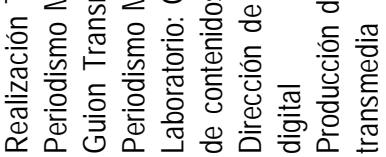

त $N$ मं
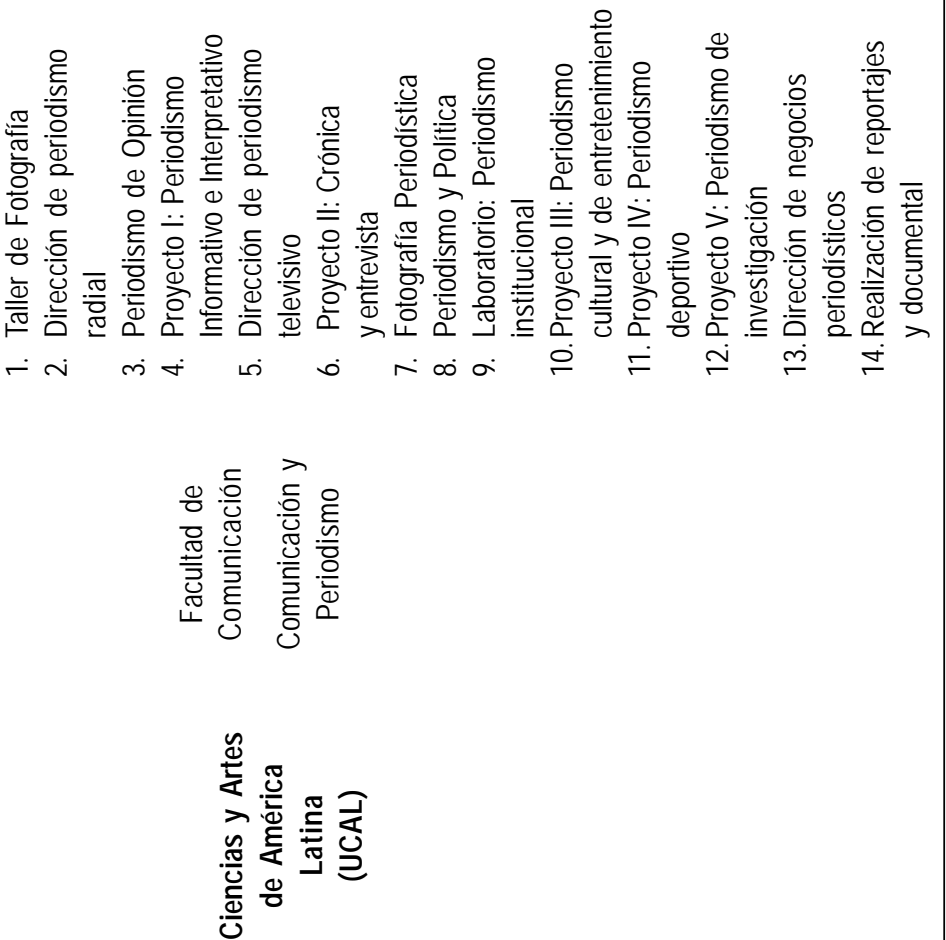

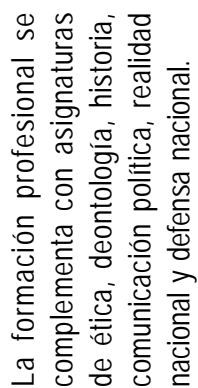

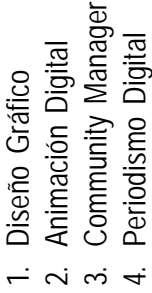

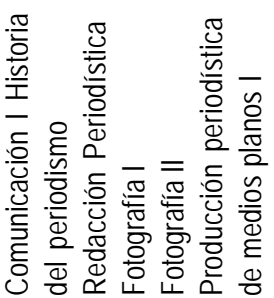

- $N$ ल
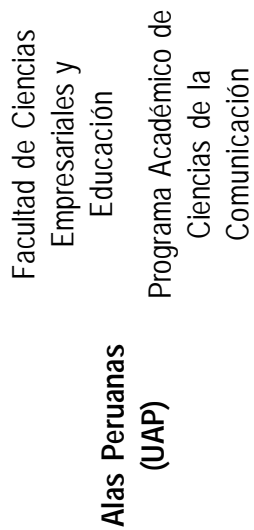


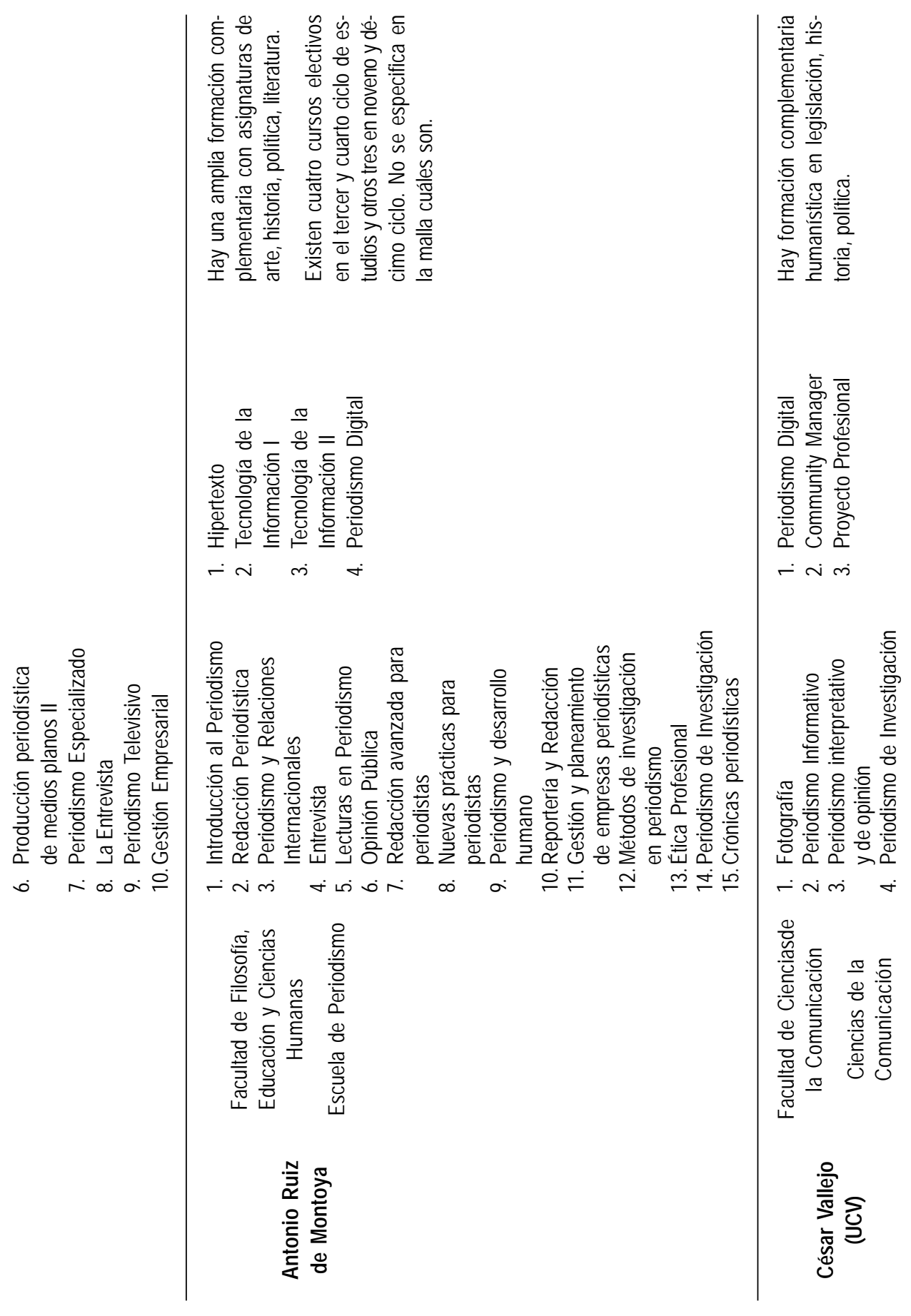




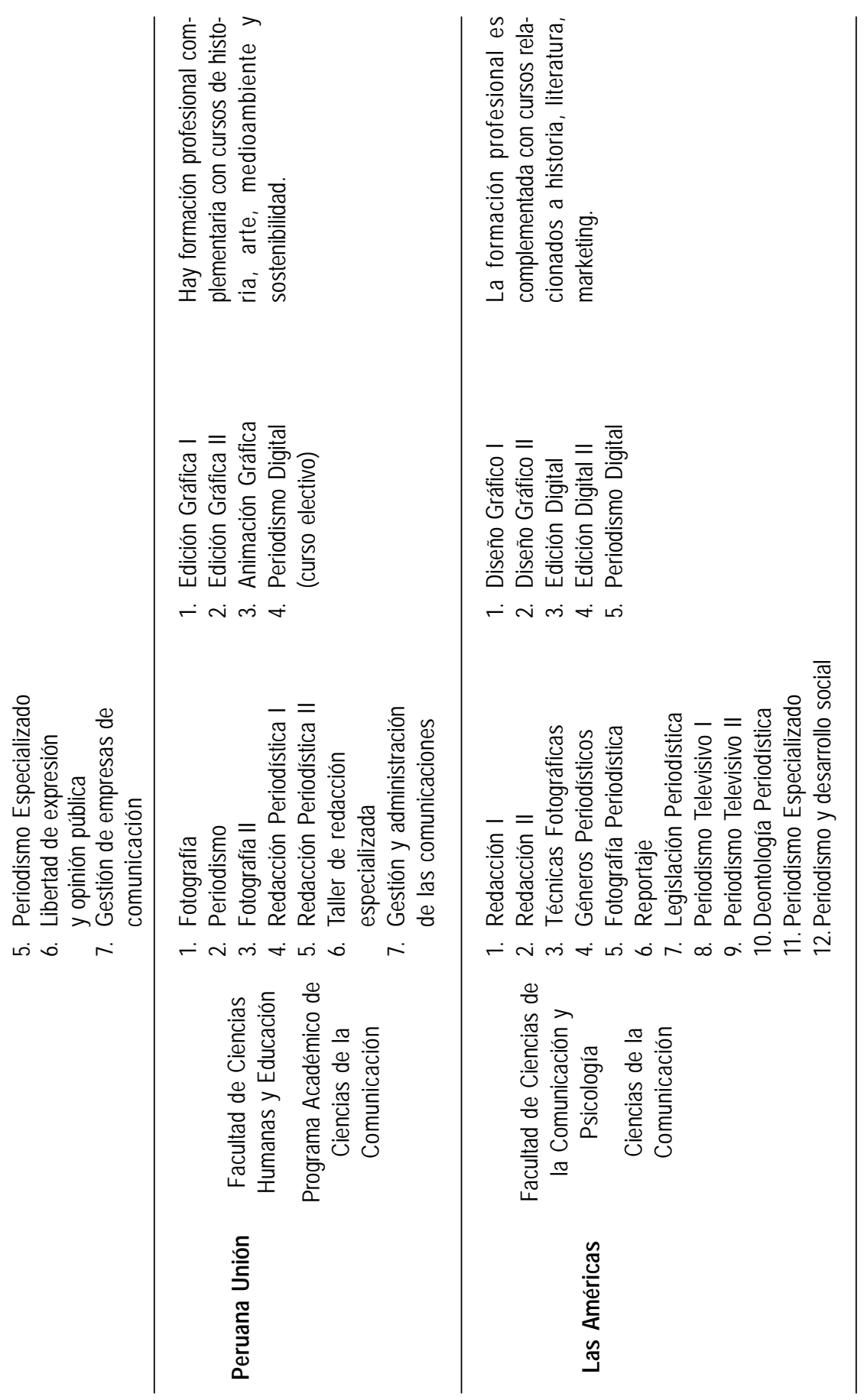



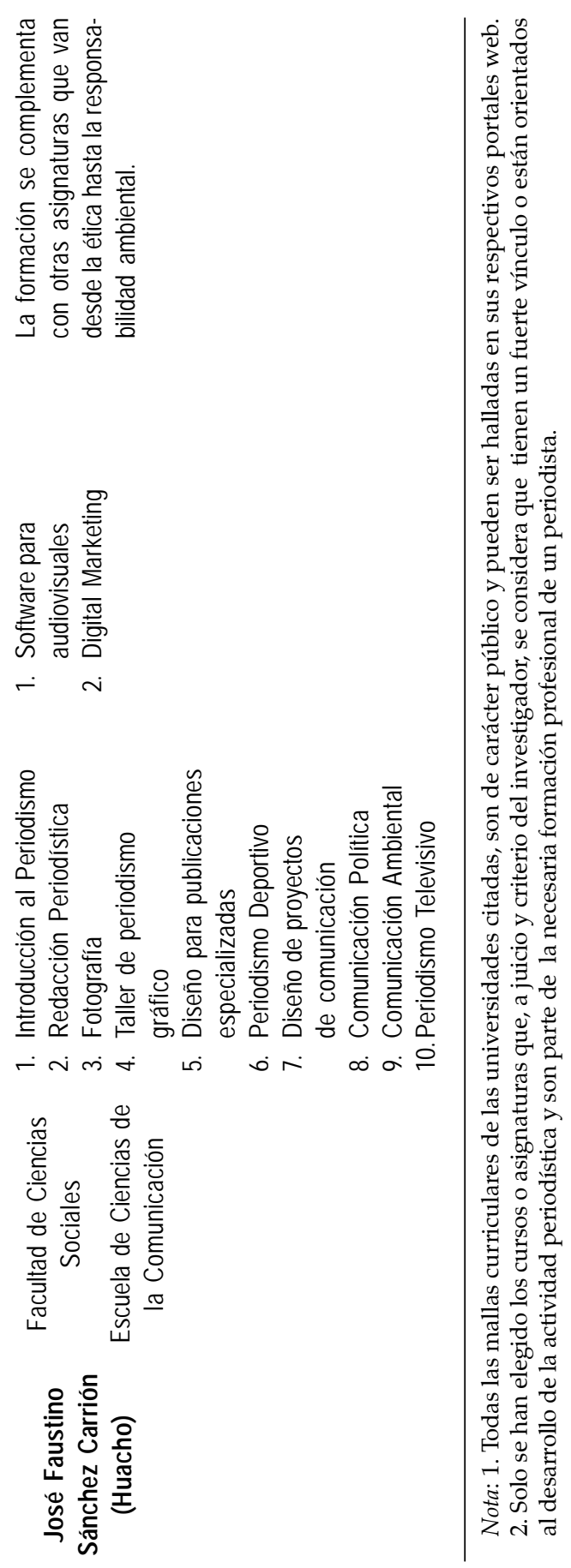


\section{La importancia del periodismo (y los periodistas)}

El buen periodismo es necesario. Un país que se autoproclame libre, democrático y con instituciones sólidas, depende en buena parte de la labor del periodismo y, por consiguiente de la seriedad, independencia y profesionalismo de sus periodistas. Periodismo político, periodismo de investigación, periodismo de ciudad, periodismo internacional, periodismo digital, periodismo transmedia, son solo aristas de la enorme responsabilidad que tiene un hombre de prensa frente a la sociedad y sus múltiples problemas, sobre todo en un país que requiere integración social, construir ciudadanía y fortalecer su democracia.

El doctor Javier Darío Restrepo, veterano periodista y miembro del Consultorio Ético de la Fundación Gabriel García Márquez se refiere al respecto:

El periodismo es importante como registro histórico, como expresión de la sociedad, como desarrollo del conocimiento y porque fundamenta la libertad de personas y de sociedades. La historia contemporánea no se podrá escribir sin tener en cuenta el registro diario de los hechos que hace la prensa. Sea mediante la palabra escrita, o a través de las imágenes de la televisión o con la ayuda de la memoria sonora de la radio, el periodismo aporta elementos que, a pesar de sus limitaciones en exactitud, en análisis o en enfoque, contribuyen a la conservación de la memoria colectiva. Pero la más conocida razón de la importancia del periodismo es que, al servir como canal de expresión de la sociedad, impulsa cambios en la historia [...] Anoté arriba una tercera razón: el periodismo contribuye al desarrollo del conocimiento de la realidad. Las informaciones diarias son un primer elemento que, cuando se procesa mediante la crítica, la contextualización, los antecedentes y la proyección del hecho, la confrontación de fuentes y las aplicaciones del hecho, convierten la información en conocimiento. Ese conocimiento es la base de la libertad. Una sociedad no puede ser libre si no conoce la realidad de lo que sucede. En efecto, cuando se conoce bien lo que pasa, las decisiones se toman en libertad en cambio, cuando no hay ese conocimiento, sociedades e individuos son manipulables. En último término el periodismo es importante porque contribuye con su tarea, al fortalecimiento y ejercicio de la libertad. (Restrepo, 2008) 
De allí la importancia de que la formación de los hombres de prensa, en esta era de permanentes cambios sociales y políticos, se convierta en una necesidad impostergable. Se puede afirmar que si la escuela da la educación formal para adquirir el civismo y los primeros conocimientos sobre la realidad que nos rodea; la prensa, en todas sus plataformas, fortalece o distorsiona, según su fin, todo el civismo o los conocimientos que se han adquirido. El pensador y ensayista peruano Manuel González Prada, hace una reflexión al respecto, muy vigente hasta nuestros días, en el capítulo Nuestro Periodismo de su obra Horas de lucha:

El periodismo encauza los arroyos difusos de las opiniones individuales, les unifica y forma el irresistible río de la opinión pública. Según el mismo Tarde, si las literaturas sirven para testificar la existencia de una nación, los diarios aguzan la vida nacional, provocan los movimientos globales de espíritus y voluntades en sus cotidianas fluctuaciones grandiosas. El periodismo tiende, no sólo a formar el alma colectiva de un pueblo, sino la conciencia de la Humanidad. (Gonzáles Prada, s. f.)

\section{Periodistas y nuevos retos}

Resulta pertinente entonces afirmar lo importante que es contar con periodistas bien informados y capacitados, con el propósito de crear en ellos nuevos hábitos y competencias que les permita comprender la trascendencia del ejercicio periodístico. Ser innovadores, ser creativos, ser emprendedores, dentro de este proceso de luces y sombras que nos deja la convergencia y sus nuevas rutinas profesionales.

Eso nos obligar a repensar también la manera como se está haciendo periodismo. Creer que la plataforma digital es simple y llanamente una copia, un espejo de lo que se publica en el soporte papel, es un error grave e insostenible en el tiempo. La falta de creatividad e innovación cierra una importante y, tal vez la más grande puerta de generación de contenidos propios, con historias nuevas, diferentes, capaces de cautivar al nuevo lector del siglo XXI, que ha dejado el papel para tomar el control total de la pantalla de su teléfono inteligente o de su tableta.

La reinvención del New York Times (NYT) apuntó en ese sentido y nadó contra corriente al negar el hecho de que todo estaba en el periodismo de papel. 
Topics del New York Times es, sin duda, el mejor ejemplo de creatividad, innovación y de buen periodismo que, con el paso del tiempo, se ha ido especializando junto a sus periodistas por la variada temática de sus contenidos.

Grandes temas como la migración, el medioambiente, la inseguridad ciudadana, la salud pública, los derechos humanos, el feminismo, la educación, los conflictos sociales, la ecología, etc. son los nuevos contenidos que generan atención y controversia, pero que requieren fundamentalmente de explicación.

En el caso del Perú, los medios tradicionales y sus páginas o plataformas digitales adolecen de ese valor agregado o bien un contenido que marque la diferencia. La coyuntura ha ganado, sin duda. Otra razón es que tal vez, también hay muchos colegas que son en realidad «periodistas todoterreno» $\mathrm{O}$ periodistas polivalentes, es decir, reporteros o redactores que trabajan en todas las plataformas y en todos los formatos que les sean posibles, a veces con resultados poco halagadores. Peor, cuando hay periodistas que se inclinan por el activismo político al considerarse portadores de la verdad y hacen un periodismo a favor de y en contra de. Eso simplemente, ha sepultado la credibilidad de muchos medios de información.

No obstante, se debe admitir que en ese desacierto con el cual muchos periodistas viven y enfrentan, hay casos excepcionales en los que, por iniciativa propia, hacen buen periodismo y presentan historias que pueden formar parte de secciones similares a Topics del New York Times. En marzo pasado, El Comercio presentó un magnífico informe sobre una unidad de transporte público que circulaba por las calles de Lima sin los permisos y las condiciones básicas adecuadas para prestar ese servicio en la capital. El especial (así fue denominado) se tituló: La bestia de Petit Thouars, pues era en esa avenida donde solía transitar el vehículo infractor.

Ese ejemplo fue extraordinario, pero quizá también el único que se publique a lo largo de este año. Otros periódicos como La República, Correo, Expreso, Perú 21, parecen no tener las condiciones para difundir ese tipo de historias y han optado por hacer de sus plataformas digitales una suerte de remedos de lo que se publica en el soporte papel. La pregunta es cuánto tiempo más podrán sobrevivir en un mercado que se pondrá mucho más exigente en cuanto a contenidos periodísticos. Tal vez, el problema se halle 
en que no se aprovechan al máximo todas las posibilidades que nos da la tecnología informática.

Sobre este tema, The Knihgt Center for Journalism in the Americas, emitió el informe Periodismo Innovador en América Latina y en uno de sus capítulos se puede leer:

En la era de los datos masivos, el periodismo se ubica en una posición crucial al apoyarse en la tecnología informática para reinventar sus métodos de búsqueda, análisis y cobertura de las noticias. Si hace cinco años los reporteros que rastreaban revelaciones en bases de datos ayudados por hackers o desarrolladores eran los «nerd» de sus salas de redacción, el panorama actual es distinto: el mundo conoce desde historias puntuales de corrupción hasta investigaciones globales como los Panamá Papers, gracias a que cada vez más medios entienden los beneficios de la alianza entre reporteros y tecnólogos. (2017, p. 73)

Aun así, se debe reconocer que en el caso peruano son periodistas o comunicadores independientes los que han abierto una enorme puerta de emprendimiento y que los medios tradicionales deben mirar con respeto y como ejemplo. De hecho, se ha abierto un interesante abanico de propuestas periodísticas con la difusión de historias de interés público y que son importantes para muchos. Los casos de Ojo Público y Convoca, por ejemplo, (portales de periodismo de investigación, convertidas ahora en ONG) o Político.pe y Montonero (que son periodismo político y de opinión), se convierten en un reto y en un referente de tópicos que podría abordar la prensa tradicional mediante sus plataformas digitales, generando sus espacios y contenidos propios.

\section{Conclusiones}

Una vez contrastados los datos y hechos que forman parte de este trabajo, se puede concluir que:

1. La disrupción de nuevas tecnologías ha obligado a los medios de comunicación a consolidar sus procesos de convergencia periodística en todos los niveles, incluyendo los administrativos. No se ha tratado, entonces, 
de la simple unificación de sus redacciones. El propósito es unificar también los criterios que apunten al desarrollo de un servicio informativo con excelencia, con el fin de satisfacer las nuevas exigencias de la audiencia o lectoría que busca contenidos de relevancia social, utilidad personal y de fácil comprensión. Esto se ha observado en los diarios El Comercio, La República, RPP, Radio Exitosa y, en un aparente desarrollo, en el diario El Peruano de Editora Perú. Así también, América TV y RTP (Canal 7).

2. En este nuevo contexto, los medios de comunicación, principalmente los más grandes, han optado por la permanente selección de personal periodístico calificado y con un perfil profesional muy vinculado al manejo y dominio de las nuevas tecnologías y herramientas digitales para ser utilizadas en el proceso de producción, elaboración y difusión de información periodística.

3. Se puede afirmar que la demanda está satisfecha, ya que las universidades peruanas, y especialmente aquellas que se concentran en Lima, cumplen con preparar y capacitar profesionalmente a los estudiantes que han elegido ser periodistas, con asignaturas y talleres vinculados a las nuevas tecnologías, herramientas digitales y redes sociales, tal como se observa en las tablas del presente estudio. Los cursos de periodismo digital y periodismo multimedia son comunes en casi todos los casos.

4. Se ha observado que la preparación de los futuros profesionales de prensa se afianza con cursos básicos e indispensables en periodismo como redacción, opinión pública, diseño gráfico, fotografía, etc. La formación humanística se complementa con asignaturas de historia, política, legislación de la comunicación, ética, literatura, arte, entre otras. Sin embargo, se observa que estas materias no se ofrecen de manera uniforme en las universidades citadas y el período de clases no va más allá de un semestre académico.

5. La preparación profesional de los periodistas es de suma importancia. Se ha observado, sin embargo, que los medios de comunicación tienden a reducir los períodos de contratación y rotación de profesionales de prensa que, en muchos casos, no va más allá de los tres años en promedio. 
6. El emprendimiento periodístico es hoy una necesidad. Cientos de jóvenes periodistas que no llegan a trabajar en un medio informativo, pueden hacerlo formando su propia empresa de comunicación. La formación en tecnologías y herramientas digitales permite que el egresado pueda trabajar de manera independiente, creativa e innovadora.

7. En esa línea, la formación de los periodistas puede complementarse con cursos dirigidos al emprendimiento, gestión y administración de empresas periodísticas, liderazgo y creatividad.

\section{Referencias}

Aguado-Terrón, J. M., \& Torres, M. B. P. (2010). Convergencia y nuevas rutinas profesionales: luces y sombras del periodista polivalente en las redacciones españolas. Recuperado de https://dialnet.unirioja.es/servlet/ articulo?codigo $=3414826$

Díaz Noci, J., \& Salaverria, R. (2003). Manual de redacción ciberperiodística. Recuperado de https:// www.academia.edu/9612676/Introducci\%C3\%B3n_Manual_de_Redacci\%C3\%B3n_Ciberperiod $\%$ C3\%ADstica

González Prada, M. (s. f.). Horas de Lucha. Recuperado de http://evergreen.loyola.edu/tward/www/gp/libros/ horas/horas6.html

Oliva, C. (2014). El periodismo digital y sus retos en la sociedad global y del conocimiento. Recuperado de http://www.redalyc.org/articulo.oa?id=495950257004

Real, E., Agudiez, P., \& Príncipe, S. (2007). Periodismo ciudadano versus periodismo profesional: ¿somos todos periodistas? Recuperado de https://revistas.ucm.es/index.php/ESMP/article/view/ESMP0707110189A/12099

Restrepo, J. (2008). Consultorio ético de la Fundación Gabriel García Márquez. Recuperado de https:// fundaciongabo.org/es/consultorio-etico/consulta/850

Salaverría, R. (2006). El nuevo perfil del periodista en el entorno digital. Recuperado de https:/l www.researchgate.net/publication/268296208_El_nuevo_perfil_profesional_del_periodista_en_el_ entorno_digital/link/54bdc6a40cf27c8f2814c85a/download

Verón, J. J., \& Sabes, F. (2008). Las nuevas tecnologías en la formación del periodista: Una necesidad inmediata. Recuperado de https://core.ac.uk/download/pdf/38977787.pdf

The Knihgt Center for Journalism in the Americas. (2017). Periodismo Innovador en América Latina. Recuperado de https://knightcenter.utexas.edu/books/PeriodismoinnovadorenAmericaLatina.pdf 